\title{
The ABC Manager-How to Manage People More Effectively in Today's Challenging and Demanding Work Environments
}

\author{
Eddie John Paul Fisher ${ }^{1,2}$ \& Yorkys Santana Gonzalez ${ }^{1}$ \\ ${ }^{1}$ Faculty of Social Sciences, Universidad de Oriente, Santiago de Cuba \\ ${ }^{2}$ Univerzita Palackeho, Olomouc, Czech Republic \\ Correspondence: Eddie John Paul Fisher, Universidad de Oriente, Santiago de Cuba, Cuba and ACSA, Brno, \\ Czech Republic. Tel: 44-1793-490-423. E-mail: eddie.fisher9@btinternet.com
}

Received: February 3, $2013 \quad$ Accepted: March 5, $2013 \quad$ Online Published: April 11, 2013
doi:10.5539/emr.v2n1p67
URL: http://dx.doi.org/10.5539/emr.v2n1p67

\begin{abstract}
Managing people well is paramount to achieving goals and objectives at work. This paper investigates and provides a deeper understanding of what positive effects knowledge and application of the concepts of attitude and behaviour can have on managers and therefore the people they manage. The results show that people skills are positively affected by the attitudes and behaviours managers develop and apply. The outcome of a literature review suggests that social psychology plays an important role in establishing how attitudes and behaviours are formed at work and the effects these have on how people think, feel and ultimately act. Outputs from a focus group meeting with practising social psychologists suggest an effective attitude, behaviour and competence skills set that, when applied appropriately, could make the difference between average and superior performance. It is suggested that people skills on their own are no longer adequate to improve the performance levels of people. The outcome of this research is applicable and relevant to managers in any working environment such as Construction, IT, Finance or Consultancy. The proposed skills set of what makes an effective attitude, behaviour and competence $(\mathrm{ABC})$ manager can be universally applied although some modifications may be necessary to meet the needs of cultural diversities.
\end{abstract}

Keywords: attitude, behaviour and competence

\section{Introduction}

\subsection{Introduction}

The role of managers has changed from just being responsible for the delivery of work and the day to day management of their team members to creating opportunities for companies to grow their business. It appears that Human Resources (HR) departments within organizations have delegated more of the day to day management of people to managers, too. This means that managers have increased levels of responsibilities for their staff. In addition, senior managers in many companies expect their managers to make the best use of available resources. In business terms, this means delivering more in less time, with fewer people and within reduced budgets. This creates tensions at work that need to be managed effectively and appropriately. Social psychology plays an increasingly important role at work. People's attitudes, for example, towards their managers, colleagues and their work, are subject to social influence. This affects the building of positive or negative attitudes. Organizations need motivated and productive staff to carry out their duties effectively and therefore ensure that the organisation remains profitable and prosperous. Organizations are also social places where people interact with each other such as colleagues, customers and supervisors. To get the best out of their people, managers need to find new ways and means of motivating and leading their team members.

This research investigates how a better understanding of the concepts of attitude, behaviour and competence-and their relationships (Fig.1)-can improve the people skills of managers. In the context of this research, the authors applied some recent definitions of attitude, behaviour and competence. Bohner and Waenke (2002) define attitude as a summary evaluation of an object of thought. An attitude object can be anything a person discriminates or holds in mind. Attitude objects may be: concrete (a pizza), abstract (freedom of speech), inanimate things (sports cars), persons (Idi Amin) or groups (foreigners).

Maio and Haddock (2010) suggest that attitudes are closely linked to behaviour. They consider that attitudes 
should predict behaviour. Behaviour is overt and can be observed. They define behaviour as an activity that covers, for example, how people act in accordance with their values, beliefs and attitudes towards people, things and institutions. The definition of behavioural competences by Gill (2011) is adopted by this research. He defines behavioural competences as the knowledge, skills and personal behaviours and characteristics that are associated with achieving corporate objectives. It appears that these are a popular method for predicting leadership success. The purpose of this research is to analyse and report what makes an effective $\mathrm{ABC}$ manager.

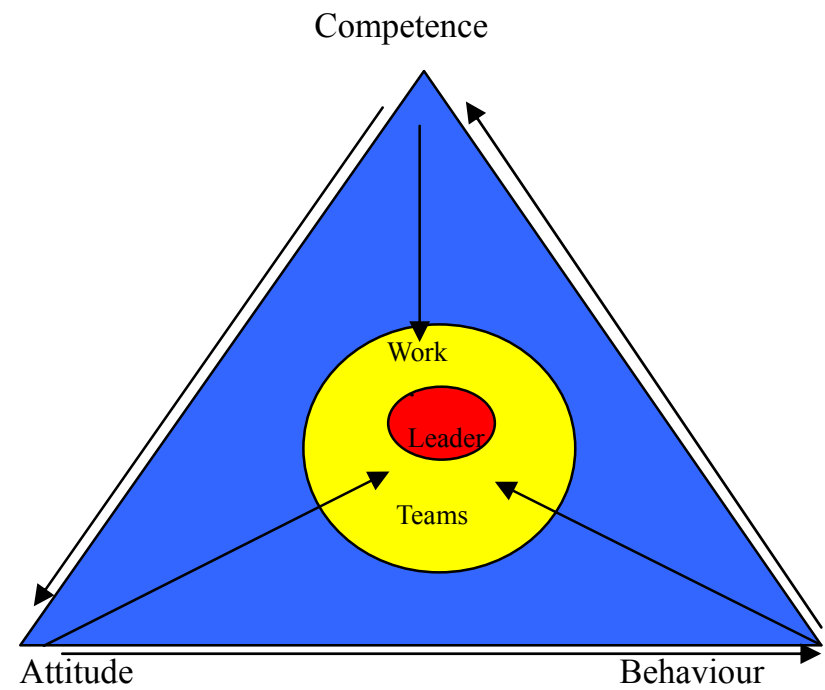

Figure1. The Relationship between Attitude, Behaviour and Competence in Work Environments

To fulfil the purpose of this research, a review of relevant recent and classis literature is presented first in the next Section. This forms the theoretical framework of this research and is followed by providing the outputs of a focus group meeting with subject matter experts in social psychology to try and close the knowledge gap considered in Section 1.2.3. The methodological approach is presented next, including details of how the research data has been analysed. The research findings are shown next which is followed by a discussion of what the research found. This is concluded in the final Section which includes this research's limitations and suggestions for future research.

\subsection{Literature Review}

\subsubsection{Attitude and Behaviour}

Management development has a long history and that of leader development is probably shorter. The importance of both cannot be underestimated (Carmichael et al., 2011). They quote Constable and Mc Cormick (1987) who suggest that there seems to be a relationship between the level of education of managers and leaders and organizational success. There is a growing importance of continued development of managers and leaders due to changes in the external environments in which organizations operate. Globally, managers and leaders have to learn how to work in these changing environments, taking account of diversities within. There appears to be a growing need for the talent pool of managers and leaders to have a changing skills set to manage the increasing diversity of businesses. A fresh set of managing people skills is needed to motivate and drive others to new levels of performance excellence.

Fisher (2011) considers that, based on the outcomes of some research, that there is a lot of scope to improve the people skills of managers. He suggests that this is particularly important in the constantly changing work environments managers operate in both at national and international level. He suggests that people skills such as effective communications, negotiating for results and influencing others are not sufficiently effective unless they are underpinned by appropriate attitudes and behaviours that drive these in an authentic and genuine way. He suggests that right attitudes and right behaviours lead to right competences in people skills managers need to have to motivate and lead people with greater levels of success.

Du Brin (2010) suggests that many scholars and managers alike are convinced that effective leadership is required to meet most organizational challenges. Many organizations recognize that good leaders of people move 
up quickly within organizations. As a result, organizations require people with appropriate managing people skills to inspire and influence others at individual level, as well as in teams, task forces and units at all organizational levels. Without effective managers or leaders at all levels within organizations, it is difficult for companies to sustain profitability, productivity and good customer service. In many different ways, researchers and practitioners have demonstrated that effective people management does make a difference. Many curricula in business schools and other fields emphasize the importance of the development of managing people skills. According to Gill (2011) behavioural competences are a popular method for predicting leadership success. In this context he defines competences as the knowledge, skills and personal behaviours and characteristics that are associated with achieving corporate objectives.

It is not necessary to have both managers and leaders (for example, people in separate roles) but managers who are leaders and leaders who are managers-people who can 'do the right thing right'. He suggests that, for example, managers maintain and leaders develop, managers focus on control and leaders inspire trust and managers accept the status quo and leaders challenge the status quo. Maio and Haddock (2010) consider that attitudes influence how people view the world, what people think and what people do. They suggest that differences in valence and strength play an important role in understanding the ways in which attitudes influence how people process information and how they behave. Attitudes can also help people express their values, identify with people they like and protect themselves from negative feedback. They further consider that knowing the primary function of an attitude is important because attempts at attitude change are more likely to be successful when a persuasive appeal matches the function of the attitude. They consider that the research on the attitude concept has continued to flourish. One of the primary themes has been the study of attitude strength.

Some attitudes are held with great strength while others are less strong. A review of some of the literature from the early years of social psychology was considered highly desirable for this research to present the influential findings from this era. Early research conducted by La Piere (1934) suggests that it is not possible to predict future behaviour if an individual's attitude is known. It appears that people do not always behave in a way that is true to their beliefs. What people say and what they do may be different. Fishbein and Ajzen (1975) suggest that behaviour may be more accurately predicted if people know about a person's intentions with respect to behaving in a particular way. The attitude-follow-behaviour principle has some implications for managers. Although they cannot directly control all their feelings, they can influence them by altering their behaviour. If managers are more task-focused than people oriented, they can become more people focused by behaving as if they were-by showing respect for others, actively listening or recognizing what is important to others. It is common to assume that attitude influences behaviour, and that, therefore, a change in attitude automatically leads to a change in behaviour.

Festinger (1964), Abelson (1972) and Wicker (1969) suggest that not all attitudes automatically lead to behaviour changes. They consider that how people feel and talk does not always act as a reliable predictor of people's actions. There is a link between attitude and behaviour but only under certain circumstances. More research may be required to shed further light on the question whether changes in attitude lead to changes in behaviour. In contrast, Gilbert (1978) suggests that the value of what people do is not in their behaviour but in what their behaviour accomplishes, in what achievements and desirable goals their behaviour produces. Accomplishments are worthy outcomes of behaviour. Behaviour in itself is important only insofar as it results in accomplishments. For example, helping others may lead to people becoming more autonomous, engaging in research may lead to the application of new knowledge and listening to new facts may lead to the application of new facts. Much later research conducted by Beer et al. (1990) suggests that there is a consistency (one follows the other as a matter of course) rather than a causal relationship between attitude and behaviour (one causes the other to happen). Their theory states that changes in attitude lead to changes in behaviour. According to this model, change is like a conversion experience. Once people get religion, changes in their behaviour will surely follow. They consider that this theory gets the change process exactly backwards: 'In fact, individual behaviour is shaped powerfully by the organizational roles people play.

The most effective way to change behaviour, therefore, is to put people into a new organizational context, which imposes new roles, responsibilities and relationships on them. This creates a situation that in a sense 'forces' new attitudes and behaviours on people' (Beer et al., 1990). This is an important point managers need to understand. They need to consider the likely consequences for adopting this approach. People may change their attitudes, for example, because they feel they have to. This leads to compliance (short-lived) rather than commitment (long-lived).

\subsubsection{Competence}


Crisp and Turner (2010) consider that someone's competence (skills) levels can be increased by the appropriate application of influence on their attitudes and behaviours. It appears that this makes people 'feel' that they have the necessary skills, and this, in turn, makes them act/react in a certain way. There is some evidence based on research that suggests that even the perception of competence is sufficient to produce certain helping behaviours. Schwartz and David (1976) found that telling someone that they are good at something will ultimately make the person act in accordance with that perception.

Perceiving oneself to be competent in one domain can even lead to that person becoming competent in another unrelated domain. They also came to the conclusion that, for example, allocating participants in a research environment to a leadership position, this increased their perceptions of competence, thus the probability of generating some helping behaviour. Stevenson and Starkweather (2009) suggest that a number of factors such as collapsing budgets, shortening of work deadlines and higher risks of failing to deliver work packages, have driven academics and practitioners to look for sources of work success. Some scholars suggest that tools and techniques are paramount to being successful at work. Others suggest that it is people who make successful work outcomes. Pant and Baroudi (2008), Wateridge (1997) and Wirth (1992) consider that the volume of scholarly commentary on the need of greater emphasis on soft skills in the training and education of managers validates the significance of human factors as a viable focal point for predicting eventual performance improvements. It appears that common sense dictates that a manager's competence is a key factor influencing the eventual outcome of work performance. Managers play an increasingly important role to help people improve themselves, work together to satisfy the needs of others and at the same time greatly improve organizational performance (Zwell, 2000).

The demands of the marketplace mandate cultural changes in areas such as becoming more customer-oriented and becoming more team-focused. To maintain competitiveness and profitability, companies have no choice but to increase their productivity. Managers are expected to get more out of people in terms of productivity and effectiveness. People are not machines and treating them as such will not work well. People have emotional needs, desires and feelings. They want to feel cared about and they have their own motivations. They will not help and support managers to achieve their objectives and those of the organization unless their own wants and needs are satisfied in the process. Zwell (2000) suggests that managers, typically, are poor motivators. To get people to work at their best, managers need to understand what drives them, what they care about and what is important to them. Employees need to be communicated to in ways that address their motivations, concerns and needs and managers need to create a work environment in which those drives and needs are met through performing the job.

He considers that managerial competences are those that determine whether someone will be an excellent manager. He considers that this competence category includes three key managerial functions: managing work packages, supervising people and developing people in order to increase their near-and-long-term contributions to the organization. Effective managers establish direction for the work and the work assignments for team members. They help remove organizational barriers and identify resources to assist them. They deal with and manage any morale problems promptly. They use a variety of approaches to energize and inspire others. By empowering others, managers can help to develop others to grow in responsibility and competence. Effective managers allow others to make mistakes and take risks to learn and grow. They also delegate responsibility to others based on their ability and potential.

It is also important to provide accurate feedback on individual strengths and weaknesses. Good managers also look after the Continued Personal Development (CPD) of team members by helping people to examine the barriers to their growth and development. Zwell (2000) suggests the following comptences as being the ones that make a substantial difference between a superior manager and an ordinary manager in performance level terms: influence, results orientation, initiative, interpersonal awareness, service orientation, integrity and truth, relationship building, analytical thinking, conceptual thinking, information gathering and being well informed how the organization works. He further suggests that competence proficiency is affected by values and beliefs, skills, experience, personality characteristics, motivation, emotional issues and intellectual capabilities.

\subsubsection{Knowledge Gap}

The literature review has revealed that social psychological research does play an important role in everyday working life such as management. Individuals form attitudes about their jobs, the companies they work for and the fairness of everyday work life. This does affect the behaviours of individuals and how they perform at work. The outcome of the literature review has not been conclusive what effects attitudes and behaviours have, in working situations, on what makes a good people manager. It appears that there is a gap between knowing about 
attitudes and behaviours and how to apply this knowledge to good effect when developing one's own attitudes and those of team members. The attitudes and behaviours of managers and their team will affect the performance of the whole team (Figure 2). In the case of people, this understanding can also help managers to develop their leadership styles and competences to become a more successful people manager.

According to Hewstone et al. (2008), organizations need motivated and productive employees to carry out their jobs and therefore ensure that the organization remains profitable and prosperous. Individual performance does not necessarily lead to the best possible outcome for the team or the organization as a whole. They suggest that an exclusive focus on individual performance can make everybody worse off because people may be unwilling to help each other, share information and pull together towards a common goal. The outcome of the literature review suggests that workplaces are social places in which individuals act interdependently. It also appears that individuals are affected by groups and vice versa (Allport, 1924). The literature review reveals that it is important for managers to understand how employees develop attitudes and then suggest interpretations accordingly.

For example, if managers know what influences their team members' impressions, they can design the terms of their relationship in a way that fosters positive job attitudes (Hewstone et al., 2008). They consider that practising managers can benefit from basic research and social psychological theories to better understand the social processes in the work place. It is found that work outcomes can be predicted when the well-established concept of social attitudes is extended to job attitudes (Figure 2).

Determinants of Job Attitudes

Job Attitudes

Work Outcomes

Job Characteristics:
Task Identity
Task Significance
Skill Variety
Autonomy
Feedback
Employment Relationship:
Group Identification
Organizational Justice
Perceived Organisational
Support (POS)

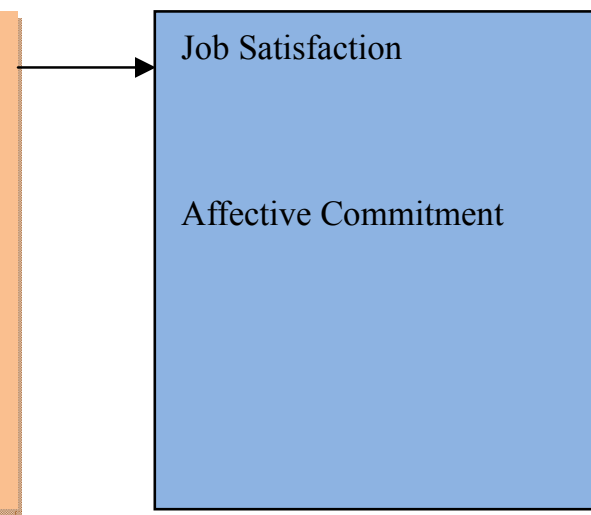

Task Performance Contextual performance Counterproductive Work Behaviour Withdrawal

Figure 2. Determinants of job attitudes and how they relate to work outcomes (Hewstone et al., 2008)

\subsection{Research Scope}

This research tries to verify the following statements:

1. Does knowledge of attitude, behaviour and competence (ABC) prepare managers and leaders better for managing people more effectively?

2. What experience exists that demonstrates that managers and leaders with $\mathrm{ABC}$ skills manage people better?

3. Are the skills needed by an ABC manager or leader similar to those needed by other managers and leaders?

4. How can existing managers and leaders better develop their people skills to become an $\mathrm{ABC}$ manager or leader?

The following hypotheses were constructed:

H1: Managers and leaders face greater challenges to manage people more effectively due to fundamental changes in organizational work practices and higher customer expectations

$\mathrm{H} 2$ : Managers and leaders with $\mathrm{ABC}$ skills are more likely to get the best out of their people

$\mathrm{H} 3$ : Managers and leaders with $\mathrm{ABC}$ skills are highly likely to move up the career ladder much faster than those without these skills

\section{Research Methodology}

\subsection{Method}


To fulfil the considered research purpose of this study and to make a valid and reliable contribution to knowledge that is of value to both academics and practitioners, the researchers considered that a qualitative research approach was appropriate, applicable and defendable for this research. It is important that managers can experience the application of the new knowledge about attitude, behaviour and competence themselves so they can have direct experience of their applications in the real world and to confirm that the research data is appropriate and can be relied upon. The researchers were seeking an understanding based on the world in which they live and work to develop subjective meanings of their experiences. These meanings were directed towards the concepts of attitude, behaviour and competence.

The goal of this research is to rely as much as possible on the participants' views of these concepts. It appears that social psychology is frequently used in scientific disciplines such as business and management but that the practical values of this discipline are not always appreciated and as such not practically applied. The researchers who conducted this research, have between 10 years and 16 years of theoretical and practical experience in social psychology such as theoretical research, practical field work with local communities, teaching at University level and publishing research outcomes at national and international level. One researcher has over 30 years of practical management experience as both a practitioner and academic researcher. This was an attempt to approach a lived experience with a sense of 'newness' to elicit rich and descriptive data.

This process is known as 'bracketing' and involves setting aside one's beliefs, feelings and perceptions so it is possible to be more open or faithful to the phenomenon under investigation (Streubert and Carpenter, 1999).

The first objective of the focus group meeting was to review the outcome of the literature review and confirm whether the research data from the literature review was relevant and admissible as evidence for this research. The second objective was to consider how $\mathrm{ABC}$ managers can apply the suggested $\mathrm{ABC}$ skills set in a practical way in real life work situations.

Buunk and Van Vugt (2008) suggest that many traditional applied social psychological topics such as conflict, aggression, cooperation in groups and leadership appear to have completely disappeared from the literature. They consider that social psychology is uniquely placed to combine good theory driven research with practical relevance. A literature review and the outcomes of a focus group meeting with psychologists from the University of Olomouc in the Czech Republic provided primary and secondary research data. A number of psychology teachers and psychology Ph.D. students were interviewed during 2012. The interviews were semi-structured. Their ages ranged from 24 years to 28 years and they had between four and ten years of experience. Their practical experience ranged from working in the areas of work and organizational psychology, management, team working and virtual team working, to working with children with mental disorders, alcohol and drug addicts and people suffering from schizophrenia. The participants were asked how they define the concepts of attitude, behaviour and competence based on their own theoretical and practical experiences from the past and the present. The researchers then focused their attention on capturing what the participants considered to be the value to managers to not only know about these concepts but what the likely practical values would be to managers to apply this new knowledge in their work environments. Table 1 is a summary of the research scope that was discussed during the focus group meeting.

The focus group reviewed and checked the findings from the literature review and made final recommendations that would be of practical value to managers.

Table 1. Research scope for the focus group meeting with psychologists

1. What is your definition of attitude, behaviour and competence?

2. What are the relationships between them?

3. Does a change in one lead to a change in the other?

4. What is the value to managers to know about these?

\subsection{Data Analysis}

This research is about how the social psychological concepts of attitude, behaviour and competence, when applied appropriately, can help managers to improve their own and their teams' performances. Dunn (2009) suggests that researchers should consider to ask questions such as 'How do we know some social psychological phenomenon is real?', 'Should we simply trust our senses?', Is the best advice to allow our intuition to guide us?' or 'What do most social psychologists do in order to convince other researchers that their observations are valid, reliable and truly descriptive accounts of some social behaviour?' The examination of the theoretical (literature 
review) and empirical data (focus group meeting), looking at both general and specific research data, was highly relevant to fulfilling the research scope (Section 1.3). Practitioners were engaged to gain new knowledge into what they suggested makes a good and solid $\mathrm{ABC}$ manager. The practical experiences and subject matter expert knowledge of this group were of paramount importance to the evaluation of the research data and its contributions to the body of knowledge in this field. This group ensured that only valid and reliable data was used to suggest what makes an effective $\mathrm{ABC}$ manager. To fulfil the desired outcomes of the research scope, the initial research issues were clearly stated (Section 1.3).Sufficient background information to the research was collected to put the main research issues into context and perspective.

Members of the focus group reviewed and validated that all research data was admissible, relevant to the outcome of the research and obtained from competent and credible sources. All research data was checked for consistency and accuracy. The focus group conducted a critical enquiry to ensure that all research data was consistent, logical and coherent to fulfil the requirements of the research scope. Practitioners make important contributions to knowledge what they propose works well in real life situations, particularly in competitive work environments. Their primary value comes from an ability to bring together theory and practice and demonstrate to managers, for example, why some managing people skills will work in certain work environments and why the same skills will not work well in other work environments or different groups of people.

\section{Results}

\subsection{Focus Group Meeting}

A focus group meeting with a number of social psychology subject matter experts from the Univerzita Palackeho Olomouci in the Czech Republic provided some contemporary insights into what makes an effective ABC manager. Attendees were conversant with current best practice in general and line management which was reinforced by the researchers through a short presentation prior to the start of the formal discussion and to set the context for the discussions. This focus group contributed to strengthen the outcomes of the literature review in a number of areas such as definitions for attitude, behaviour and competence and what the relationships are between them (Table 1 shows the full set of the research scope). The focus group confirmed that the research data from the literature review was consistent and admissible. The literature review on its own did not confirm this. The group confirmed, through relevant and appropriate discussions based on their extensive practical experiences, what they suggest makes an effective $\mathrm{ABC}$ manager. The focus group members identified that the right attitudes lead to the right behaviours and associated competences.

Applying these is what makes an effective $\mathrm{ABC}$ manager. This is crucial. Having knowledge of and developing competences, per se, is no panacea for success. The same applies to attitudes. Managers need to practically use the concepts of attitude, behaviour and competence, then review any impact that invoked changes have on people (including themselves) and then think about whether it will be necessary to adjust these in accordance with, for example, unsuccessful applications. The focus group suggested that managers should review their attitudes, behaviours and competences on a regular basis as this is an important process.

'Attitude is about how people approach work, how they interact and work with people, for example, in today's challenging and demanding work environments' (Marek). 'It is about the value people place on team work and how people value and respect team members' (Jitka). 'But it is also how people approach the general concept of having a manager to work for and how they think this relationship will or needs to work'(Pavol). 'Attitudes are expressed in our opinions about the various aspects of our lives such as sport, smoking, killing people, the environment and acceptable social behaviours '(Klara). 'I think behaviour is how people react to different situations in life' (Pavol). 'Yes, it is what people do. You can think about something but what really matters is what you actually do. It is open or overt and people can see what you can do'(Jitka). 'Behaviour is expressed in our body language. Trained people can find out through the interpretation of our body language if we actually mean/do what we say we would do or mean to do (Marek). 'Competent means being able to do something right such as driving a car or managing work' (Pavol). It is about having a set of skills to do certain or specific tasks such as flying a plane' (Marek). 'I think that competence is a personality trait. It is something that people are born with that allows them to do something well' (Jitka). 'But people are also influenced by others and their environment. This can have a major influence on developing their competence levels to do certain things to a certain level' (Marek). All students suggested that skills or competences are acquired during our lives and that there is a dependency between attitude and competence in that attitude drives the level of competence people can acquire or develop. They considered that competence can be both internal and external to the person concerned. For example, 'it is possible to observe someone's competence by studying their behaviour when they do a certain job' (Pavol). 'Internally, someone's self-esteem can help them to drive to new or higher levels of competence because they believe in their ability to achieve something' (Jitka).

The students suggested that it is possible that attitudes affect behaviour and vice versa. Attitudes are affected by 
the values people place on things. This can drive the associated behaviour(s). Behaviours can be affected, for example, by the food people eat such as chocolate. This affects endorphins (peptide hormones) in the brain that in turn affect emotions. This can affect behaviours that affect attitudes towards certain things. 'Everything influences everything' (Pavol). 'A terrorist, for example, behaves in a way that is consistent with a surreal world where only black or white exists. The real world which consists of black and white, can influence the behaviour of the terrorist thus leading to a change in their attitude towards what they believe in' (Marek). 'Drugs can influence our attitudes. They make us feel good and positive about certain things, leading to changes in our behaviour as a direct result' (Jitka). Members of the focus group suggest that managers need to develop positive or right attitudes in themselves and their team members so that they can achieve higher levels of good performance by being an effective $\mathrm{ABC}$ manager. They consider that positive or right attitudes have an influence on behaviour and vice versa: the right attitude leads to the right or desirable behaviour. It appears that the right attitudes and the right behaviours make a major contribution towards the development of associated right competences.

Table 2 is a summary of the application and rankings of the examined $A B C$ skills set. Results from this research suggest that managers who have an $\mathrm{ABC}$ skills set, are more likely to manage themselves and their teams more effectively. It appears that there is a direct relationship between the skills set and how its application will contribute to success at work in a number of ways:

1. Being able to turn negative attitudes and behaviours of people into positive ones

2. Improve the team's ability to execute action taking

3. Improve the positive synchronisation of team members' perceptions about the work they do, the manager they work for and the company that employs them

4. Build and maintain improved interpersonal relationships with the team

5. Foster a working environment where the right attitudes, behaviours and competencies are valued

6. Improve the work skills and competence level of each team member

7. For managers to improve their own managing people skills

Table 2. Application and ranking of the examined ABC skills set

\begin{tabular}{|c|c|}
\hline ABC Set & Application \\
\hline Attitude and & Attitude cannot always be used to predict future \\
\hline Behaviour & $\begin{array}{l}\text { behaviour-people do not always behave in accordance with } \\
\text { what they believe in. }\end{array}$ \\
\hline & $\begin{array}{l}\text { There is a relationship between attitudes and behaviours but } \\
\text { only under certain circumstances. Sometimes people say one } \\
\text { thing but do something different. }\end{array}$ \\
\hline
\end{tabular}

Behaviour is overt. Changes in behaviour that lead to accomplishments can be observed. People can be judged by what they actually do.

Recent research suggests that a change in attitude automatically leads to a change in behaviour. Changes in work situations 'force' people to change their attitudes and then their behaviours.

Positive reinforcements are necessary to achieve repeat behaviours, for example, in similar situations in work environments.

Attitudes influence how people view things, what they think and what they do. Knowledge about the primary function of an attitude is important. A persuasive appeal can help to change the attitude in question.

Positive attitudes have the potential to lead to positive responses or behaviours. Verbal and non-verbal responses are considered to be observable behaviours.

Competence Competence levels of, for example, team members can be increased by influencing people's attitudes and behaviours. This applies to existing and new competences.

Dimensions of behaviour are relevant to job performance. Attitudes affect competence.

Knowledge of what makes an effective $\mathrm{ABC}$ manager can help organisations to improve their work delivery capability.

Ranking
Considered important by all*
Considered highly important by
all. The focus group suggests
that this is an integral part of
being an effective ABC
manager * all
Considered important by all
$*$

Considered important by the literature review.

Considered highly important by all *

Considered important by all*

Considered highly important by all.*

Identified by all as being highly important for managers to know about and to act upon * Considered important by all *

Considered highly important by the focus group members

\footnotetext{
*Literature review and focus group meeting
} 


\section{Discussion}

Contextual performance such as helping team members and the manager is increasing in importance in today's working environments. Employees not only have to deliver their own work but also have to work together as a team to create work environments that foster individual and team performance. Social contexts in working environments affect the thoughts, feelings and behaviours of individuals (Hewstone et al., 2008). This paper suggests how knowledge of the relationships between attitude, behaviour and competence could, if adopted, help managers to improve their own and their team members' performance by managing themselves and their staff more effectively. The result will be increased levels of productivity in today's and tomorrow's fast-paced working environments. The outcome from the literature review and focus group meeting suggests that a positive attitude affects how people feel and think and that this affects their behaviours and competences at work. Managers who adopt a positive attitude towards everything they do, feel or think are more likely to act in accordance with that attitude. The associated behaviours are overt and can be observed by their team members.

This is not sufficient on its own. Managers need to influence their team members to adopt similar positive attitudes and associated behaviours and sell team members the benefits for doing so. Managers need to be the driving force behind this approach. They are ultimately responsible for the work performance levels of their team, both at individual and team level. They need to motivate and encourage team members to follow their lead. Managers need to experience first for themselves how a change in their attitude leads to positive changes in the way they perform at work and how they interact with other people. They can achieve higher levels of performance and commitments to do well within their team members by developing stronger attitudes within them to identify much better with the tasks they need to do and generate higher levels of feelings of their own significance associated with the completion of these tasks.

People will become more autonomous and develop stronger group and organizational identities. This leads to higher levels of motivation and a willingness to do well in everything they do. Support for the manager will also increase and this could lead to a much closer professional working relationships. This will also affect how the other team members work. It is sometimes referred to as the knock-on effect. The individual skills of people are important but the strength of the team depends on how people connect or combine. A well-balanced attitude and associated behaviours improve work performance levels as this creates a synergistic effect of the team. Effective $\mathrm{ABC}$ managers can positively influence their own as well as the behaviours of their team members. Working closely with team members opens up opportunities to create higher levels of job satisfaction within the people they manage. This leads to improved levels of job performance which includes affective commitments to do well.

A better understanding of the relationship between attitude and behaviour can contribute to improved levels of competence within people with the result that higher levels of performance develop. It is also possible that counterproductive behaviours can be reduced, provided that managers use this knowledge and understanding effectively. It is important to keep team members motivated to reduce the likelihood of their withdrawal from the work they do due to, for example, a lack of interest or feelings of not belonging to the team.

The outcome of the literature review suggests the theory of what it means to be an $\mathrm{ABC}$ manager but it is the knowledge of the practical applications from the participants that has made a significant contribution to bring theory and practice much closer together. Social psychology plays an increasingly important role in working environments such as general and line management.

Its strength lies in its ability to make a difference to both theory and practice in the area of managing people through the appropriate application of the concepts of attitude, behaviour and competence. Knowledge and understanding of the concepts of attitude, behaviour and competence is not a panacea for automatic and unconditional success. It is a lengthy process managers need to review regularly to observe, for example, the likely impact any changes have on themselves and their team members and then consider what modifications they may have to instigate to make these work more effectively. The three hypotheses of this research are supported by strong evidence from the literature review and the focus group meeting with practitioners (see Table 3 for a summary of the results), namely:

H1: Managers and leaders face greater challenges to manage people more effectively due to fundamental changes in organizational work practices and higher customer expectations. This hypothesis holds true. Greater emphasis will be needed to train managers and leaders in $\mathrm{ABC}$ skills.

$\mathrm{H} 2$ : Managers and leaders with $\mathrm{ABC}$ skills are more likely to get the best out of their people. This premise is valid. More emphasis needs to be placed by organizations on the importance of $\mathrm{ABC}$ skills so they can develop managers to become superior performing managers. 
H3: Managers and leaders with ABC skills are highly likely to move up the career ladder much faster than those without these skills. This is a valid hypothesis. Managers with ABC skills are worth more to organizations as they can help companies to increase not only performance levels of staff but also to grow the business.

Table 3. Hypotheses and research scope: summary of results

\begin{tabular}{|c|c|c|}
\hline Hypothesis & Related Research Question(s) & Results \\
\hline $\begin{array}{l}\text { H1: Managers and leaders } \\
\text { face greater challenges to } \\
\text { manage people more } \\
\text { effectively due to } \\
\text { fundamental changes in } \\
\text { organizational work } \\
\text { practices and higher } \\
\text { customer expectations }\end{array}$ & $\begin{array}{l}\text { 1. Does knowledge of the concepts } \\
\text { of attitude, behaviour and } \\
\text { competence (ABC) prepare } \\
\text { managers and leaders better for } \\
\text { managing people more effectively? } \\
\text { 2. What experience exists that } \\
\text { demonstrates that managers and } \\
\text { leaders with ABC skills manage } \\
\text { people better? }\end{array}$ & $\begin{array}{l}\text { The evaluation of the literature was } \\
\text { positive but not conclusive to determine } \\
\text { the practical applications of the ABC skills } \\
\text { set. The focus group concluded that } \\
\text { managers who adopt and apply the ABC } \\
\text { skills set will make superior contributions } \\
\text { to increase productivity at work and will } \\
\text { help to grow the business of the company } \\
\text { they work for. }\end{array}$ \\
\hline $\begin{array}{l}\mathrm{H} 2 \text { : Managers and leaders } \\
\text { with } \mathrm{ABC} \text { skills are more } \\
\text { likely to get the best out of } \\
\text { their people }\end{array}$ & $\begin{array}{l}\text { 2. What experience exists that } \\
\text { demonstrates that managers and } \\
\text { leaders with ABC skills manage } \\
\text { people better? } \\
\text { 4. How can existing managers and } \\
\text { leaders better develop their people } \\
\text { skills to become an ABC manager } \\
\text { or leader? }\end{array}$ & $\begin{array}{l}\text { The literature is positively conclusive and } \\
\text { provides valid and reliable evidence that } \\
\text { suggests that knowledge and experience of } \\
\text { attitudes and behaviours act as enablers } \\
\text { for managers to increase the performance } \\
\text { levels of their staff at work. }\end{array}$ \\
\hline $\begin{array}{l}\text { H3: Managers and leaders } \\
\text { with } A B C \text { skills are highly } \\
\text { likely to move up the career } \\
\text { ladder much faster than } \\
\text { those without these skills }\end{array}$ & $\begin{array}{l}\text { 2. What experience exists that } \\
\text { demonstrates that managers and } \\
\text { leaders with } \mathrm{ABC} \text { skills manage } \\
\text { people better? } \\
\text { 3. Are the skills needed by an } \mathrm{ABC} \\
\text { manager or leader similar to those } \\
\text { needed by other managers and } \\
\text { leaders? }\end{array}$ & $\begin{array}{l}\text { The literature is positively conclusive that } \\
\text { managers with ABC skills are more likely } \\
\text { to become superior performers and thus } \\
\text { move up the career ladder much faster } \\
\text { than managers without this skills set. } \\
\text { Because of the low number of answers } \\
\text { from the focus group participants, the } \\
\text { focus group contributions do not allow, on } \\
\text { their own, to fully determine whether } \\
\text { managers with ABC skill sets will get } \\
\text { promoted faster or not. }\end{array}$ \\
\hline
\end{tabular}

\section{Conclusions}

There is no conclusive evidence from the literature review and the insights from the community of practice that, for example, a change in attitude does lead to a change in behaviour in every conceivable situation or circumstance. Knowing about someone's attitude is no panacea for success to predict their likely behaviours-people say one thing and then do something else or people share their intentions to do something and then do something else. Managers need to invest more of their time to understand what attitudes team members hold, for example, towards the work they do, the company they work for, their colleagues and their customers. They need to build effective rapports and relationships with team members by being genuine, open and honest with those who they work and interact with. They need to show an authentic interest and concern for others that are based on true feelings and not constructed or made up feelings.

Managers need have a number of behaviours so they can deal with people in a variety of work situations such as conflicts, grievances or short term high pressure situations in project work environments. Adopting this approach, it is highly likely that managers will get much more closely to finding out what the true attitudes of people are and why they hold these. It is then possible for managers to develop improvement plans how to positively influence, for example, those attitudes and associated behaviours of people that are highly desirable to be changed. It is of practical value for managers to understand that attitudes influence how people think, what they value and how they view the world. It appears that there is a positive relationship between attitudes and 
behaviours and how levels of someone's competence can be increased through positive influences on these. This research further suggests that behaviour in itself is not so important but what the behaviour actually achieves is very important.

This paper suggests what the skills of an effective $A B C$ manager are. The literature review provided valuable knowledge what was already known about attitude, behaviour and competence and to consider how this could be used more effectively by managers to improve their own, individual and team performance at work The adoption of the $\mathrm{ABC}$ skills set suggested by this paper acts as a catalyst to help managers understand better the relationships between attitude and behaviour and the potential effect this can have on the development of appropriate competences at both personal and team member level. The practical application of this skills set makes a substantial difference how managers manage themselves and their team members. When applied appropriately, it is possible to develop higher levels of self-confidence, interpersonal skills, interactions with team members and a more focused and results oriented team. It is considered that the adoption of the new ABC skills set will guide managers to manage so-called 'I or we cannot do this' attitudes and associated behaviours. It will be possible for managers to turn negative and inappropriate attitudes, their own and those of their team members, into positive attitudes such as 'I or we will find another way to resolve this work issue'.

The research was limited to a small number of psychology Ph.D. students and psychology teachers from the faculty of Psychology at the Univerzita Palackeho Olomouci in the Czech Republic. Insights and subject matter knowledge from a larger sample of students and their teachers of other Universities, including those in other countries, would have provided richer and diverse research data to address the research scope in more depth and universally.

This research was influenced by and conducted in accordance with previous research by Fisher (2011). It is confirmed that the research scope from Section 1.3 has been answered and that all three hypotheses hold true and are valid in the context of this research.

\section{References}

Abelson, R. (1972). Are attitudes necessary?. In T. King, \& E. Mc Ginnies (Eds.), Attitudes, Conflict and Social Change (Vol. 13, p. 130). New York; Academic Press.

Allport, G. W. (1924). Social Psychology. Cambridge: MA: Riverside Press.

Beer, M., Eisenstat, R., \& Spector, B. (1990). Why change programs don't produce change. Harvard Business Review, November-December.

Bohner, G., \&Waenke, M. (2002). Attitudes and Attitude Change. Psychology Press Ltd.

Buunk, A. B., \& Van Vugt, M. (2008). Applying Social Psychology-From Problems to Solutions. Sage Publications Ltd.

Carmichael, J., Collins, C., Emsell, P., \& Haydon, J. (2011). Leadership \& Management Development. Oxford University Press.

Constable, J., \& Mc Cormick, R. (1987). The Making of British Managers. London: British Institute of Management and Confederation of British Industry.

Crisp, R. J., \& Turner, R. N. (2010). Essential Social Psychology (2nd ed.). Sage Publications Ltd.

Du Brin, A. J. (2010). Principles of Leadership (6th ed.). Cengage Learning.

Dunn, D. S. (2009). Research Methods for Social Psychology. Wiley-Blackwell.

Festinger, L. (Ed.) (1964). Conflict, Decision and Dissonance (Vol. 13, p. 78). Stanford: Stanford University Press.

Fishbein, M., \& Ajzen, L. (1975). Belief, attitude, intention and behavior. Reading, MA: Addison-Wesley.

Fisher, E. J. P. (2011). What practitioners consider to be the skills and behaviours of an effective people project $\begin{array}{llll}\text { manager. International Journal of Project Management, 29, 994-1002. } & \text {. }\end{array}$ http://dx.doi.org/10.1016/j.ijproman.2010.09.002

Gilbert, T. (1978). The behavior engineering model. In T. Gilbert (Ed.), Human competence: Engineering worthy performance (pp. 73-105). New York: McGraw-Hill.

Gill, R. (2011). Theory and Practice of Leadership (2nd ed.). Sage.

Hewstone, M., Stroebe, W., \& Jonas, K. (2008). Introduction To Social Psychology-A European Perspective (4th ed.). BPS Textbooks, BPS Blackwell. 
La Piere, R. T. (1934). Attitudes versus Action (Vol. 13, pp. 230-237). Social Forces.

Maio, G. R., \& Haddock, G. (2010). The Psychology of Attitudes and Attitude Change. Sage Publications Ltd.

Pant, I., \& Baroudi, B. (2008). Project management education: the human skills imperative. International Journal of Project Management, 26(2), 124-128. http://dx.doi.org/10.1016/j.ijproman.2007.05.010

Schwartz, S. H., \& David, T. B. (1976). Responsibility and helping in an emergency: effects of blame, ability and denial of responsibility. Sociometry, 39, 406-415. http://dx.doi.org/10.2307/3033505

Stevenson, D. H., \& Starkweather, J. A. (2009). PM critical competency index: IT execs prefer soft skills. $\begin{array}{llll}\text { International Journal of Project } & \text { Management, }\end{array}$ http://dx.doi.org/10.1016/j.ijproman.2009.11.008

Streubert, H. J., \& Carpenter, D. R. (1999). Qualitative research in nursing: Advancing the humanistic imperative ( 2 nd ed.). New York: Lippincott.

Wateridge, J. (1997). Training for IS/IT project managements: a way forward. International Journal of Project Management, 15(5), 283-288. http://dx.doi.org/10.1016/S0263-7863(96)00085-3

Wicker, A. W. (1969). Attitudes versus actions: The relationship of verbal and overt behavioral responses to $\begin{array}{llllll}\text { attitude objects. Journal of } & \text { Social }\end{array}$ http://dx.doi.org/10.1111/j.1540-4560.1969.tb00619.x

Wirth, I. (1992). Project-management education: current issues and future trends. International Journal of Project Management, 10(1), 49-54. http://dx.doi.org/10.1016/0263-7863(92)90074-J

Zwell, M. (2000). Creating A Culture of Competence. John Wiley \& Sons, Inc. 